

\section{Disgraced of the West, Deserted of the East: \\ Men in the Films Shame and Issiz Adam (Alone) ${ }^{1}$}

\section{Introduction}

Steve McQueen is a sophisticated director that creates different art forms including photography, short films, sculptors and installations. He has resounded with his film Hunger (2008) which won the Caméra d'Or in Cannes Film Festival. Hunger tells the story of the last days of a man called Bobby Sands (acted by Michael Fassbender) who was in a hunger strike in 1981. His second feature film Shame was released in 2011 and Fassbender was the lead actor again. This time McQueen told the story of a man who is sex addict. In 2013, McQueen released his third film 12 Years A Slave which won a Golden Globe Award and an Academy Award for best picture in 2014. McQueen digs into real life problems and shows spectators little known or ignored parts of the stories. In Shame, he presents a man who is sex addict and hides some clues into the film why he is. Although obsessions and addictions are not new into movies, a character who is vulnerable to the sexual activities is. The character Fassbender acted out is the reflector of the fragile conditions of human beings. Brandon and his sister Sissy's behaviors and addictions they have force spectators wonder about their past. His insecure relationships, sex addiction, loneliness and his pain are very close to Alper, Çağan Irmak's main character in Issiz Adam (Alone, 2008). 


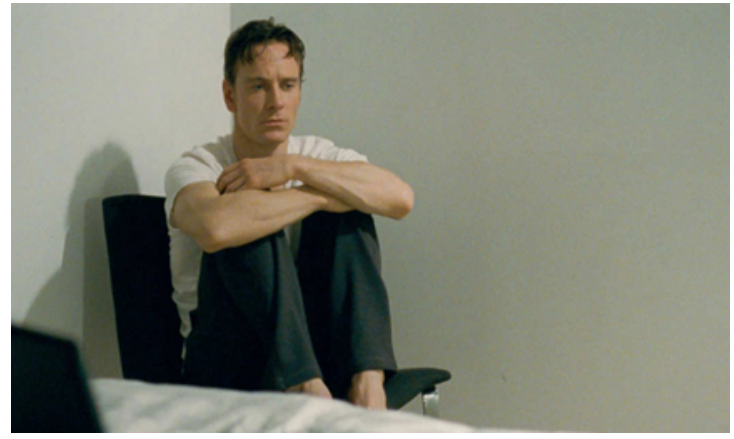

Figure 1: Brandon in Shame

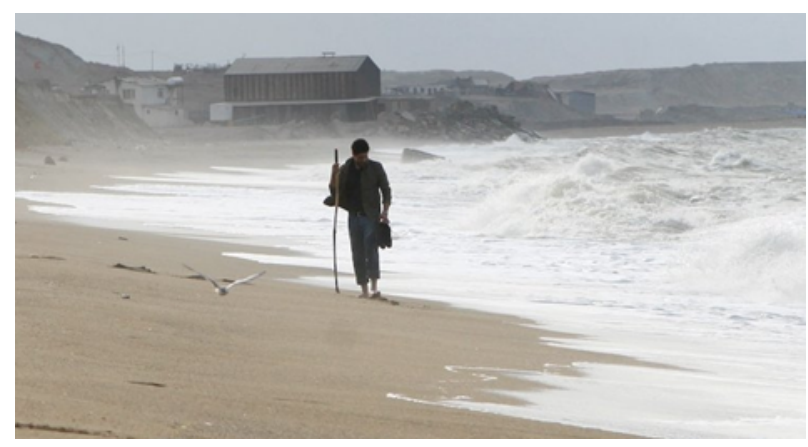

Figure 2: Alper in Issiz Adam

Çağan Irmak is a Turkish director who is famous for his TV series Çemberimde Gül Oya, Asmall Konak and his feature films Issiz Adam (Alone) and Babam ve Oğlum (My father and My Son) with which he won Turkish Cinema Writers Association Awards for Best Film, Best Screenplay and Best Director. Çağan Irmak is known for his usage of melodramatic features deeply in his films. In his films, it is almost unusual not to cry, not to feel sorry for the people in the story. However, his sixth feature film Issiz Adam is the most exceptional of all. Even though it still has melodramatic features and lamentable scenes, the main character Alper has similar aspects of Brandon but in a more eastern way.

Most of Çağan Irmak's films consist conflict of modern and traditional, big city and country or yesterday and today. That's the reason his films are mainstreams and watched by a large mass. However, Issiz Adam shows a man who has sexual fantasies and actualize these fantasies in his daily life. Issız Adam's opening scene shows Alper arranging some sexual meetings via Internet and this meeting includes group sex. In a romantic Turkish film, it is unusual to show fantasies 
and a man who has group sex including another man. However, like Brondon, Alper is alone, addictively has sex and has attachment problems. He hides his feelings, does not trust people and has almost no friends. Even though Brandon and Alper seem indifferent characters, they represent modern men living in big cities with fear of love, being vulnerable and lonely. Brandon only once shows an attempt to have a relationship but he fails. In Shame, there is not a love story because Brandon's past hunts him. In Issiz Adam, there is a love story but Ada is the one who carries the love. Even Alper tries to love Ada and have a relationship with her, he fails too.

In this sense, Issiz Adam and Shame share a common feature of a problem of lack of Adult Romantic Attachment theorized by Hazan and Shaver (1987). Both characters cannot have proper relationships with people and they cannot attach women as their romantic partners. They both have sex addiction on different levels and they both suffer from the consequences of not being attached. As Katehakis states (2017) there is a correlation between insecure attachment and sex addiction. They also suffer from being masculine in the twenty first century that complicates the adjustment to the norms. Behind attachment problems, there are childhood stories or past issues. The following section tries to look more closely at the romantic attachment theory and masculinity in millennium and contribute the analysis of both films. 


\section{Adult Romantic Attachment}

Attachment theory (1969) which was originally formulated by John Bowlby has been one of the major groundworks for the study of romantic relationships. According to Fraley and Shaver (2000, p. 132), one of the reasons for the popularity of theory is its arrangement of a groundwork that explains development, maintenance and disintegration of a close relationship and its perspective on personality development, emotion regulation and psychopathology. In 1980, Hazan and Shaver developed the theory by adding romantic adult relationship models showing the individual differences in infant attachment patterns. Although attachment theory was constructed to define the emotional bond between infants and their caregivers, the critical point was to know the importance of attachment in human existence. Bowlby thought that attachment has a big role in adults' lives:

The formation of a bond is described as falling in love, maintaining a bond as loving someone and losing a partner as grieving over someone. Similarly, threat of loss arouses anxiety and actual loss gives rise to sorrow while each of these situations is likely to arouse anger. The unchallenged maintenance of a bond is experienced as a source of security and the renewal of a bound as a source of joy. Because such emotions are usually a reflection of the state of a person's affectional bonds (Bowlby, 1980, p. 40). 
However, until the mid-1980s researchers did not begin to take seriously the probability that attachment processes may occur in adulthood. According to Hazan and Shaver (1987), a motivational system occurs between infant and caregiver also develops between adult romantic partners. Upon this expression, some researchers began to notice that many lonely adults report troubled childhood relationships with parents or with their romantic partners suggesting that attachment history influences the frequency and form of adult loneliness (Rubenstein \&Shaver, 1982; Shaver \& Hazan, 1987; Weiss, 1973). It is found out that individuals have unique attachment stories related to the relationship with their early caregivers. If the caregivers are warm, lovely and consistent, children learn that others can be counted on when needed and if the caregivers are cold, unpredictable or insensitive children have negative feelings about people around them (Hazan \&Shaver, 2000, p.135). These negative or positive working models will shape the relationship of individuals throughout life as they are believed not to change fast. Hazan and his friends (1987) investigated attachment in a self-declarative scale in romantic relationships, which Ainsworth's designated triple attachment style is the adult's counterparts, especially in the context of intimate relationships, and they also defined three dimensions for adults as secure, anxious-indecisive, and anxious-avoidant attachment styles. According to this, adults with a secure attachment style are self-confident, socially entrepreneurial individuals who are not bothered by establishing close relationships, and anxious-indecisive adults are 
individuals who do not trust themselves and are afraid of rejection and abandonment. Anxiousavoidant adults, on the other hand, are observed to avoid close relationships, are uncomfortable with opening themselves and are socially suppressed. Most of the researchers working with adult attachment styles use the quartet attachment model developed by Bartholomew and colleagues on the self and other models (Cooper, Shaver \& Collins, 1998).

As romantic relationships are compelling to people's lives, having a healthy one is important in the sense of feeling satisfaction both physically and psychologically. The style of attachment is one of the most important determinants in one's quality of life (Feeney, 1996; Jacobsen, 2003; Marchand, 2004). Based on the early definitions of attachment, Bartholomew and his colleagues (Bartholomew \& Horowitz, 1991) put together the two types of self and other internal working models proposed in Bowlby's original theory and defined an adult attachment style model, which they call the four-category model. From this point of view, they set out from the positive or negative perception of the self and others and put forward four patterns: secure, obsessive, indifferent and fearful attachment. In Turkey, a study was conducted by Sümer et al (1999) showing the validity and reliability of these attachment styles on the Turkish sample, and a pattern similar to the western sample was obtained. These four 
attachment styles are considered to be prototypes that individuals fit more or less depending on where they come across on each employee model dimension.

According to the Quadruple Attachment Model, while adults with secure attachment perceive themselves as valuable and lovable, others are also accessible and sensitive. Securely attached people have high self-esteem, are not bothered with intimacy and have autonomy. In the remaining three attachment styles, there is a negative internal working model regarding the self and / or others, and all three are included under the name of insecure attachment. Adults with obsessive attachment find themselves worthless while evaluating others positively; so they try to gain the approval and acceptance of others and become too busy with relationships.

While these people desire to be in close contact with others, they are able to distance others from themselves because they want to have a sticky relationship with them. In the fearful attachment style, the self is seen as worthless and the others are also viewed negatively. The person has beliefs that he or she is unworthy of being loved and that others are rejecting. For this reason, individuals with fearful attachments avoid establishing intimate relationships or experience considerable problems in their relationships. Indifferent adults, on the other hand, evaluate themselves as valuable and lovable as well as have negative evaluations towards others. Individuals with indifferent attachment styles are disappointed. They want to avoid 
close relationships in order not to be exposed and rejected, and thus try to be independent and strong and maintain their positive self-perception.

\section{Romantic Attachment Styles and Sexual Addiction}

\section{Sex Addiction}

Sex addiction is one of the topics that has been debated so far. Even though it is still a question

if sex addiction exists, there are some parameters that are used to measure the average and excessive rates. According to Carnes and Wilson, addiction is a term traditionally associated with alcohol or drugs, now it also consists of other compulsive behaviors such as overeating, gambling or sex. When sexual behavior is irresistible and continues in spite of having detrimental outcomes then it is called sex addiction (2013, p. 4-5).

Steve McQueen's second feature film Shame is about a man called Brandon Sullivan (Michael Fassbender) who is lonely and has intense sex addiction. Even though for some researchers there is not a clear explanation of how much sex is enough or how much sex is too much, the movie focuses on the immense amount of sex a man is having and portraits of his life. According to McQueen, the director of the movie Shame, this subject of having sex addiction was an urgent one to dig into as there are many people suffer from this situation all around the world. The debate over sex addiction is difficult as it is sensitive, private and in most cases a 
taboo. That's why bringing out such a taboo subject with its multilayered dimensions is difficult and a shocking experience for the audience.

Sex addiction is not a topic to debate alone without its detrimental consequences such as physical, social, occupational, financial and psychological (Shaffer \& Albanese, 2005). Craving is one of the identifiers of addiction that dominates a person's life. Brandon's craving starts on his way to work on the subway in the morning. As he is preoccupied with sexual fantasies and behaviors, he tries to seduce women around him even during a short journey. Brandon smiles at a young attractive woman on the train and her engagement ring does not stop him to chase her. Brandon lacks focus at work as he is still preoccupied with sexual fantasies. While thinking about watching pornographic videos in his office, he suddenly realizes that his computer has been taken away and found excessive pornographic content on the hard drive. As his computer is taken away, he needs another break from work to masturbate in the washing room. He continuously creates a moment to feed his sexual appetite. Brandon's sexual preoccupation continues after work too. Almost every night he has sexual activities with either woman from a bar on the street or a sex worker in a hotel room. As a result of these activities, it is clear that Brandon is so lonely and he cannot have a romantic relationship with any women. 
Different from Brandon in Shame, Alper (Cemal Hünal) in Issiz Adam (Alone) has not a sex addiction but a burst to try to have different sexual activities including fantasies. Issiz Adam is the sixth feature film of Turkish director Çağan Irmak who is known with his films filled with emotion. Even though Issiz Adam is also a romantic drama filled with love and emotion, it is also one of the Turkish films that has a protagonist who lives his sexual fantasies openly and has a group sex including a man in it. Although it is not openly declared, it is obvious that Alper has sex with both genders. He also has regular sexual activities with some middle- aged women for money. After sex, he never sleeps with the women, rushes them out of the house and gets everything cleaned. As Brandon has the obsession of cleaning the toilet seat and flush it out after masturbating in the washroom, Alper has the obsession of having clean sheets after sex.

Alper's sexual activities do not detain him running his business during the day. As a chef and the owner of a restaurant in a respectable district, it is even clear that when he serves good food to the food critics, he has the pleasure of doing his job successfully. However, Alper is as alone as Brandon because Alper cannot have feelings for women and cannot have a relationship. Despite not as much as Brandon, Alper has sexual cravings too. While he is pouring himself 
into his restaurant during the day, he needs sexual activities either with people he meets online or women for money during the night.

Researches demonstrate that there is a correlation between insecure attachment and sexual addiction (Faisandier, Taylor, \& Salisbury, 2011; Katehakis, 2017; Zapf, Greiner \& Carroll, 2008). Even though the reason of sex addiction is still not known, as Bancroft and Vukadinovic suggest it may often have its origins in attachment deficits and inadequately developed affect regulation mechanisms (2004). It is believed that early childhood attachment traumas drive adults to develop insecure attachments especially in their romantic relationships. As Benfield indicates:

They experience relationships as unsafe. These individuals struggle with regulating their own emotional experiences and are unable to turn to other people for co-regulation. Instead, they find a "safe" substitute in terms of a substance or behavior that momentarily acts to soothe the difficult emotional state. In the case of sex addicts, this is compulsive sexual behavior. While the behavior may help them to feel better in the short-term, it does not address the underlying problems of insecure attachment and inadequate affect regulation (2018, p.13).

Brandon and Alper have different childhood backgrounds. While little known about Brandon's family, Alper has a traditional big family lives in a small town. In Brandon's life the only connection to his childhood is his sister Sissy (Carey Mulligan) who seems to have borderline 
personality disorder. Despite being the only family member of Brandon, it is obvious that Sissy is not welcome to his life again because there is an awkward intimacy from Sissy to his brother. While staying at his place, she attempts to snuggle up to his brother naked or leaves suggestive messages to his phone. There is a blurry relationship between siblings in the film which evokes romantic incest questions.

\section{Romantic Incest Relationship}

Brandon and Sissy's family background is complex and problematic. In a part of the movie Sissy says "we are not bad people; we just come from a bad place" which sounds a confession about their past. Romantic incest relationships, according to Richardson, follow the same narrative trajectory from a shared childhood to a tragic end $(2000 ; 555)$. With this tragic end, it is referred to death. However, all romantic incest relationships do not need sexual intercourse, there may have intense brother and sister bond. As Richardson gives example from the stories of Wordsworth's White Doe of Rylstone and Scott's Waverley:

A brother and sister share an unusually intense sibling bond, although they do not become erotically entangled are nevertheless separated by death at a point when they would otherwise be left together in exile or isolation (2000, p. 56). 


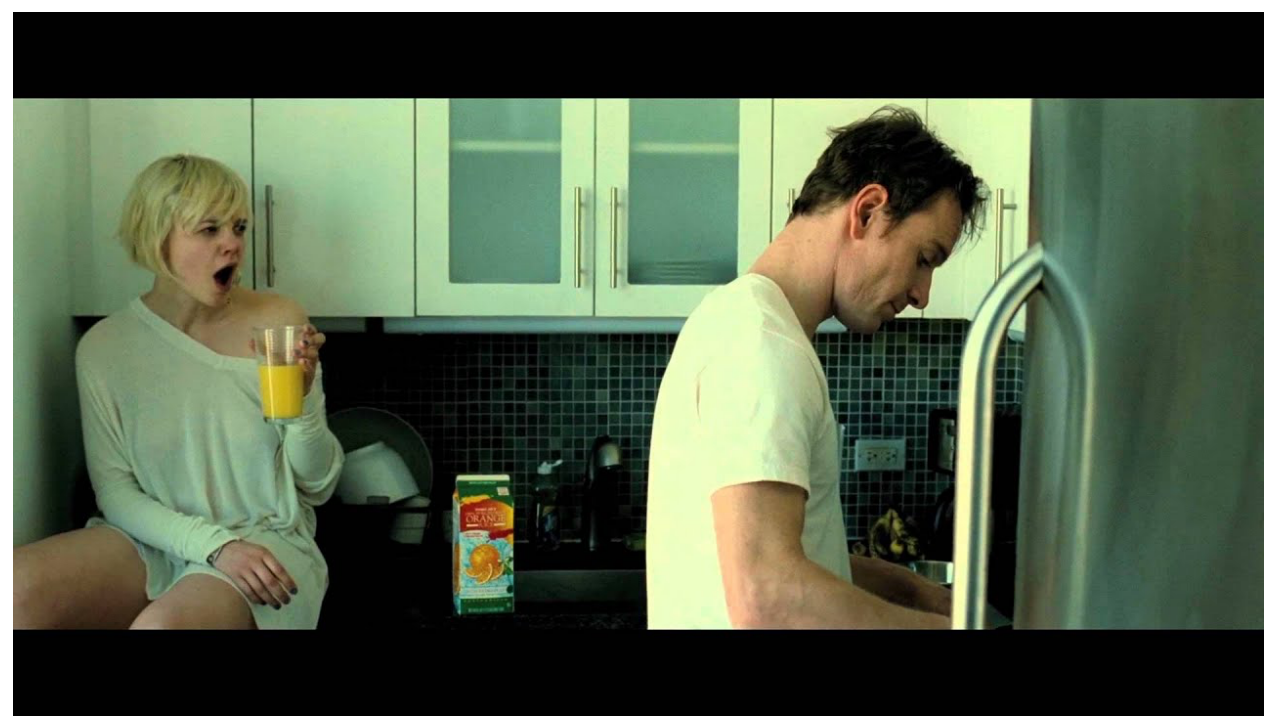

Figure 3: Brandon and his sister Sissy, trying to have a healthy relationship together

In the movie Shame, it is not easy to say that Brandon and Sissy have a sexual intercourse but the relationship between them seems as in the description of Richardson's: intense brother and sister bond. It is the probability that because of the place they had to live and the situations they had to bear in their childhood they may have the feeling of love and security to each other and they may be the first caregivers of each which enables kids to have attachment that affect their relationships with other people when they become adults. For Brandon, it is not easy to leave Sissy behind even though he tries. When he ignores Sissy, she cuts her wrists in his apartment and makes him feel guilty and responsible to her. It is not easy for both of them to cope with the problems they had in their childhood. Both of them struggle to continue their lives either having addictions or psychological disorders. Not knowing about their parents or family 
members alive makes audience to think that they do not have any other people around them to trust or to get help.

The fact that they grew together having no one but each other around to love and trust may have created the situation of "if being of the same nature be exposed for an indefinite time to same impressions and associations, all their particular differences will, at last, be overruled, and they will become perfectly similar or even equal (Hartley, 1834). As siblings share the same basic nature, environment and memories, they create their perspectives about the world together. The pure love they have each other can be confusing in the sense of sexual intimacy. Although the tragic element of romantic incest has been tried to be examined under the theory of Freud's unconscious fear of incest (Richardson, 2002, p. 558) Westermarck had a different approach to the romantic incest topic and tried to examine "remarkable absence of erotic feelings between persons living very closely together from childhood" (Westermarck, 1925, p.192) and carried the subject another level. However, studies carried in 2000s show that even though Westermarck's theory is correct to some point, the existence of social pressures and norms cannot be avoided. Accordingly, for Brandon and Sissy the social norms and taboos are on the table as Brandon tries hard to stay away from Sissy in order not to spark her feelings 
about being close. Being each other's first care givers and probably the first people feeling love affect both Brandon and Sissy to have healthy romantic relationships.

\section{Adult Loneliness and Love}

The concept of loneliness indicates the negative experiences that the individuals experience when the subjective perception of the breadth and quality of their social environment and the social environment they wish to have does not match in terms of quality and quantity (Lee ve Ko, 2018; Perlman and Peplau, 1984; Russell, Cutrona, McRae and Gomez, 2012). Some individuals state that although they are clearly isolated from their social environment, they do not feel lonely, others feel lonely despite having a rich social environment in terms of interpersonal interaction (Lykes and Kemmelmeier, 2014). Such individual and situational differences seen in loneliness experiences show that loneliness has a multi-dimensional structure (Rokach, 2001; 2012).

In this context, three main components are emphasized in the conceptualization of loneliness. The most basic component is the state of deprivation caused by the lack of close attachment in interpersonal relationships. The second component, which is related to the time perspectives of individuals, includes optimistic / pessimistic comments about the future and subjective evaluations about whether their loneliness will pass over time. The third component includes 
emotional experiences such as sadness, grief, guilt, shame, disappointment, and despair (de Jong-Gierveld, 1987; 1998).

Humans are creatures that cannot live alone, coexist with others and seek close relationships. The intimate relationship or love is sometimes used to denote a personal relationship, sometimes a special element or feature of personal relationships, and sometimes a certain feeling one person feels for another. The important thing here is that there should always be one "other" person for intimacy or love. To Sternberg (1999), love or romantic relationships are dramatically important for some people as they believe that love gives meaning to their lives. Moreover, scientifically it is stated that love has some important functions in human life.

Kernberg (1998), describes love as the abandonment of self-limits in the existential dimension. His description of love has the explanation of the fear of love in both male characters. When they have feelings to the specific women, both of them give almost the same reactions. In Issiz Adam, Alper runs after Ada (Melis Birkan) to have attention of hers but his intention is not to fall in love as he never loves but always has sex. After he wins the back the favor of her, she accepts to have a dinner at his house. 


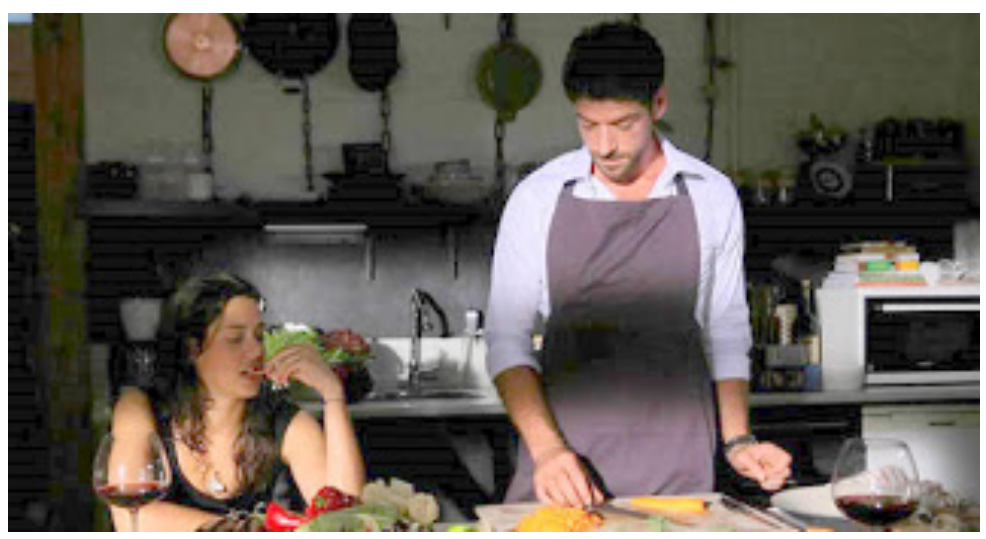

Figure 4: Besides having sex, Ada wants to build a relationship with Alper

As he is a chef, he promises to cook delicious food to her. After they kiss, Ada understands that they will have sex but she does not want to as she believes the sex in the first date makes men feel having a score. However, she cannot resist and they start to have sex. Alper tries to have sex as he is used to with paid women; rude, quick and without any passion. Ada tries to stop him as she feels uncomfortable and something goes wrong. Alper pre-ejaculates and apologizes from Ada saying he does not know the reason. Upon this, Ada tries to teach him how to kiss, how to touch a woman's body and how to move together. Alper has a new kind of excitement and he gets orgasm. After sex as she stays and sleeps next to him, he feels uncomfortable and leaves her in the bed and goes out.

It is almost the same situation for Brandon. The women Brandon is with are either impersonal or anonymous. But when he goes out one night with a woman from his workplace, he realizes 
how difficult it is to have a relationship with a woman that he can have feelings to. In the restaurant, every minute is difficult and awkward as he is not familiar with the rituals of a date.

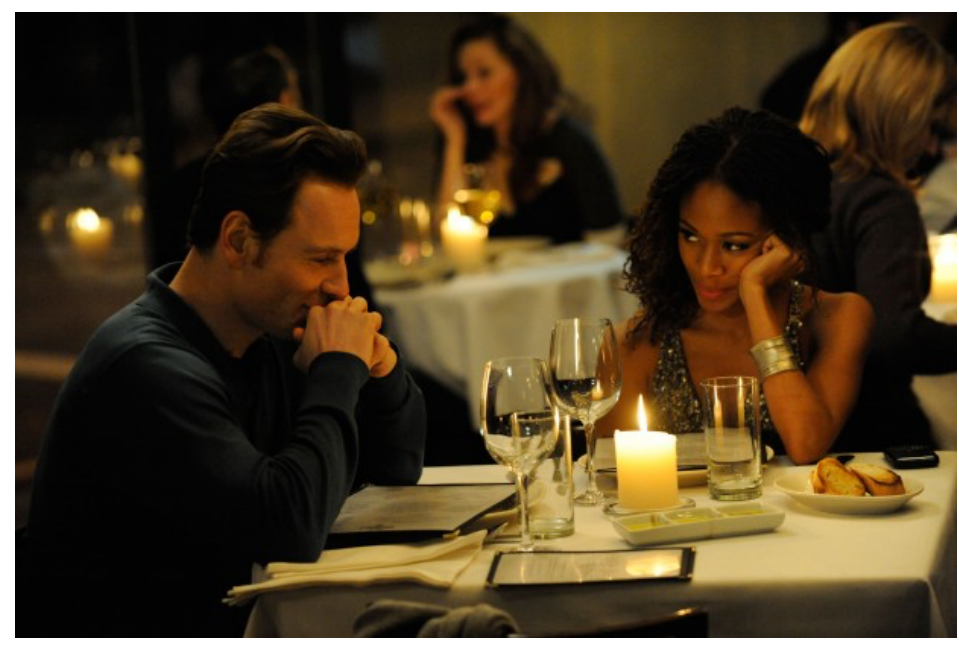

Figure 5: Brandon tries to give a chance to have a relationship

During the dinner, he mentions his thoughts about getting married and says he finds it unreal as his longest relationship was four months. According to Lee (2004) and Johnson (2012), real relationships require rejection, communication, vulnerability and disclosure. Being close and intimate is the most difficult one if someone has problems with communication and the attachment story of childhood is one of the reasons of these kind of behaviors (Johnson, 2012; Katehakis, 2010). When it is obvious that they will have sex, Brandon needs a substance to make himself comfortable and he gets some cocaine. However, like Alper, he fails to have sex because he cannot get an erection. He gets out of the bed and sits in a corner of the room with a shame. After his workmate leaves the room, we see him in the same room having sex with a 
paid woman against a window. Now he is able to have sex but his thoughts linger in his mind.

Even though he proved himself that he can have sex with a woman again, his ability to have a relationship and to feel attached to someone is insufficient. According to some clinicians, having sex addiction is an intimacy and relationship disorder (Katehakis, 2010; Schnarch, 1991; Zapf, Greiner, Carroll, 2008). It is apparent that Alper and Brandon have difficulties to have intimate relationships. Their bodies give reaction to the unknown feelings and their selflimits are endangered in unknown territories.

However, both of them try to change their behaviors as they realize the level of their addictions. While Alper tries to communicate, sleep, share some time with Ada and even introduces her to his mother, Brandon cleans up his apartment from pornographic materials, sex toys even from his laptop as if he tries to get rid of the shame he feels. Nonetheless, both fails.

Alper's mother comes to visit his son and she will attend a wedding ceremony. Alper cannot have communication with his mother either. That's why he asks Ada to help his mother in shopping and hang around with her. For Alper, his mother is extremely traditional and represents the life he ran away. It is obvious that one of the reasons Alper moved to a big city is to get lost. He cannot communicate, he has sexual fantasies which his family would not approve and he does not want to get stuck in traditional family issues. He prefers speaking his 
mother on the phone and sends money occasionally when she needs. Even though he misses to have a family, his habits and addictions stop him.

For Brandon, his only family is his sister and they have a blurred past that stops him to get closer to her. However, it is obvious that Brandon is lonely. He does not have a real friend; the people he has contact with during the day are paid women to have sex and to avoid his loneliness he constantly does activities including sexuality. As Alper, in this big city he is lost too. The last scene of the movie Shame while Brandon wears his headsets and runs through the street represents his loneliness and desperation. The same loneliness and desperation hit Alper too at the end of the movie Issiz Adam. After Alper breaks up with Ada with no reason, he feels free again. However, after a while his loneliness hits his face. He deeply regrets his decision and he breaks down. Alper and Ada come across in a café five years later.
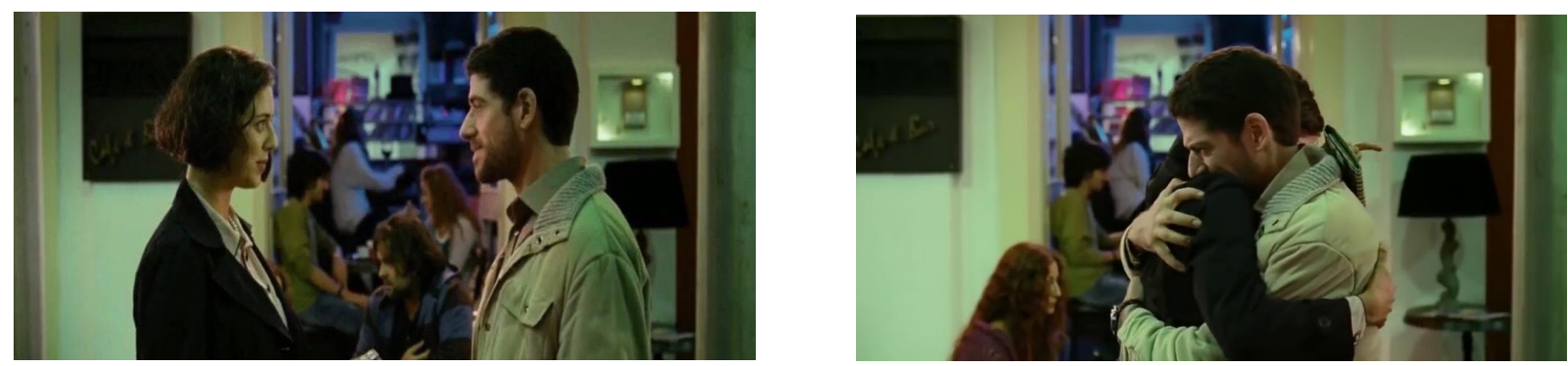

Figure 6-7: After five years, Ada and Alper still feel regret about their incomplete love

Ada moved to England, got married and had a daughter. Alper is still alone and to feed his hunger for having a family, he becomes the uncle of his workmate's son and tries to make him 
happy as he knows he won't have any kids. When Ada mentions his family and shows her daughter's photograph to Alper, he deeply feels his fault again knowing that the girl in the photograph would be his own daughter.

So as Brandon and Alper have attachment-related anxiety (Gillath, Karantzas and Fraley, 2016) they prefer having attachment-related avoidance to feel safe and secure as they want to live in their familiar boundaries. In order to run out of their fears they keep themselves busy with sexual activities and as they believe they do not need relationships they force themselves to 'deny the importance of close relationships' (Gillath, Karantzas and Fraley, 2016). Apart from having attachment stories and problems, both suffer from being masculine living in big cities and torn to pieces between norms of the society and their feelings.

\section{Masculinity in Millennium}

Romantic attachment stories need to be discussed with the consideration of gender approach of the culture and the specific era. While feminism has a longer history, male gender roles studies started in 1950s concerning the critical study of men, values, male perspectives and their practices. Itulua-Abumere states that masculinity has passed through three theoretical waves. The first wave considered the problematic male roles, male ideology and dominant expectations. Second wave came into being in 1980s and focused on centrality of male power and how to be dominant. Third wave has been affected by the feminist post-structuralism and 
post-modernity (Itulua-Abumere, 2013, p. 42). Third wave also includes Butler's theories of masculinity as she states male and masculinity studies go hand in hand with "the possibilities to subvert and displace those naturalized and reified notions of gender that support male hegemony and heterosexist power" (Butler, 2005, p. 90).

Society's power to determine masculine qualities is as unstable as the concept itself. Since the concept of masculinity has different definitions and characteristics according to time, place, history and culture, it can only be studied as a kind of diversity and complexity. In this sense masculinity in Shame and masculinity in Issiz Adam and the problems male characters have are different although they have something in common: they cannot love and they cannot attach. Masculinity has always come with the word crisis. Male are in crisis because of modernization, women, changing gender equalities, changing relationship models etc. Yet, male crisis becomes an important issue as it effects "the construction of masculinity, economic and institutional structures and the dynamic of gender" (Connell, 1995). While boys start to play competitive sports, for example, they start to have their places in constructed and organized institutions of manhood. As biology is not the destiny for women, and everything is learned, thought socially, culturally and historically, manhood and masculinity has the same paradigm 
that is constructed socially and historically. As Morgan states, masculinity and femininity are not what men or women do but what they are (1992).

The new millennium brought some questions related to men while new expectations are on the way. What is to be man, or what it means to be masculine questions were on the agenda. However, the reason of these questions were asked was the changes that were challenging masculine norms. The hegemonic masculinity described by Connell (2005) had traits such as unemotional, sexist, dominant, powerful and aggressive (Maclness, 1998). These traits were taken for granted for men and were feeding patriarchy and giving more dominant positions to men. When these traditional norms are challenged, men are confused to adapt the new ones as hegemonic patriarchy still dominated the culture and the society.

While the movies of 1980s celebrated hyper masculine men, 1990s did the opposite and created new man that is a nurturer (Beynon, 2002) and also metrosexual. There was a big confliction about new masculinity that was described as sensitive but tough, wealthy enough to get education in great schools but a boy from the neighborhood and these conflictions were creating the stereotypes of new masculinity. Although it is thought that new millennium would end the masculinity, it just pretended the departure from manhood of 1990s (Malin, 2005) and carried it to 2000s with its anxieties. There appeared movies with themes of split personality 
between soft and hard men, feminine men or invisible men only comes visible when they create chaos or act against masculine traits.

In both films, the main characters have attachment problems as they cannot balance between the new and the old traits. In Shame Brandon feels alive and validated when having sex as he can control everything. He is afraid of his feelings and pushes his fears under while having a

life that is a big shame in the society. Alper on the other hand, plays Casanova but torn between love and being single as being single refers being free. Brandon suffers from being alone in a big city where almost everyone is left alone while Alper tries to get lost in the big city as his traditional family traits follow him. It might be said that both male characters feel visible while having sex and feeding their masculine parts. It is not a coincidence that both Alper and Brandon have sex with unknown women but cannot start or continue a relationship including emotions.

\section{Conclusion}

Even though McQueen does not disregard women's experiences, he prefers to interrogate masculinity through his main characters to see the edges in his films. The second movie of a masculinity trilogy Shame stands in between perfectionism and hopelessness. Brandon is a man 
who is as handsome as Greek statues, attractive and has ability to seduce any women to have sex. He is represented as an ideal man. However, he suffers from his numbness and emotionless as if he trapped in a prison. An ideal masculine story should include a man who is confronted physical challenges and he by his own nature should overcome of it. Yet, when he is forced to face himself and questions his validity, he can torture both himself and people around him. This hits the face of Brandon and he becomes the shame of his own life.

The same story is valid for Alper either in Issiz Adam. Alper is represented also as handsome, successful at his job and has ability to seduce women. He is not after love but he is after sex. He does not promise to be committed or to have a relationship. His challenge is being out of his element and show a different image of him to his family and his coworkers. He has a split personality. When he started a relationship with Ada, he had to stay more than he can in his front life. His fear of love, being attached one specific person and necessity of changing his life style forced him to move away at the cost of left alone.

Attachment Theory that was put forward by Bowlby was developed with the name of Romantic Attachment Theory by Hazan and Shaver. This theory suggests that romantic attachments also follow the same patterns with infant attachments and they are related with some problems occurred in babyhood. According to researches, many lonely people report troubled childhood relationships with their caregivers or with their romantic partners in their relationships. 
Although Issiz Adam and Shame have different cultural backgrounds, both films focus on lonely men living in big cities, cannot have romantic relationships and having big crisis in their lives. Both men have sex addictions on different levels as their cultural background permits and both of them suffer from the battle they have inside. While Brandon has troubled childhood and in spite of desiring to have a proper relationship with his sister he can't because their attachment story is complicated. On the other hand, Alper who is supposed to go after Ada- the one he ran after for sex yet he was supposed to be with her as she was approved both by his mother and the spectators - is one of the most memorable characters in Turkish film history not because he leaves his partner in the honeymoon stage of their relationship and enjoys being single and "free" but because he carries the cumulative cultural and masculine norms that is believed that make men feel trapped and he is the reflection of those city men in the beginning of the twenty first century.

Alper's life style and attachment problem in his relationships has become a syndrome called Issiz Adam Syndrome in Turkish. After the movie shot in 2008, thousands of people saw movie more than once with the hope that Alper would change his idea about not being with Ada. This aspect of Alper also shed light on the deep loneliness of the audience and the most fundamental needs such as being seen, loved and owned. Many people cried their eyes out as they believe 
that this movie is all about their lives. On the other hand, Brandon's life style and his pain horrified people because he was suffering even he was having sex -the most frequent action he has involved in. He is so alone that in spite of his beauty, power and obvious luxury life style he can commit suicide any minute. He is in a worse condition than Alper because he is not even closer to have an intimate relationship in his life. Brandon is compelled to do the same mistakes and suffer from the same results every day.

In conclusion, analyzing both male characters' situation shows that those men living miles apart in different cultures experience similar results of adult romantic attachment anxiety together with the common norms of being men in the twenty first century called shame for the West and alone in the East.

\section{REFERENCES}

Akser, M. (2016). Changing LGBT narratives in Turkish cinema. Reconstruction: Studies in Contemporary Culture, 16(2), 1-9.

Bancroft, J., and Vukadinovic, Z. (2004). Sexual addiction, sexual compulsivity, sexual impulsivity or what? Towards a theoretical model. Journal of Sex Research, 41(3), 225234.

Bartholomew K, Horowitz LM. (1991). Attachment styles among young adults: A test of a four- category model. J Pers Soc Psychol 61: 226-244.

Benfield, J. (2018) Secure Attachment: An Antidote to Sex Addiction? A Thematic Analysis of Therapists' Experiences of Utilizing Attachment-Informed Treatment Strategies to Address Sexual Compulsivity, Sexual Addiction \& Compulsivity, 25:1, 12-27. 
Beynon, J. (2002). Masculine and Culture. Open University Press.

Butler, J. (1990). Gender Trouble: Feminism and the Subversion of Identity. Routledge.

Bowlby, J. (1980). Attachment and loss: Vol. 3, Loss: Sadness and depression. New York: Basic Books.

Çağlayan, E. (2020). Stalkers of Istanbul: Silence, Urban Space and Damaged Masculinity in Nuri Bilge Ceylan's Distant. Quarterly Review of Film and Video, 1-18.

Carnes, P. and Wilson, M. (2013). The Sexual Addiction Assessment Process. In K. Adams, P.

Carnes (Ed.).3-19. Clinical Management of Sex Addiction. Brunner-Routledge, Great Britain.

Connell, R. (2005). Masculinities (2nd ed.). Cambridge: Polity.

Cooper, M., Shaver P.R., Collins, N. (1998) Attachment styles, emotion regulation and adjustment in adolescence. J Pers Soc Psychol 74: 1380-1397.

de Jong-Gierveld, J. (1987). Developing and testing a model of loneliness. Journal of Personality and Social Psychology, 53(1), 119-128.

Faisandier, K., Taylor, J., \& Salisbury, R. (2011). What does attachment have to do with outof-control sexual behaviour? New Zealand Journal of Psychology, 40(3), 19-29.

Hartley, D. (1834). Observations on Man: His Frame, His Duty and His Expectations. Sixth Ed. Thomas and Son: London.

Hazan, C., \& Shaver, P. (1987). Romantic love conceptualized as an attachment process. Journal of Personality and Social Psychology, 52, 511-524.

Itulua-Abumere, F. (2013). Understanding Men and Masculinity in Modern Society. Open Journal of Social Science Research, 1(2): 42-45. 
Iwen, M. E. (2015). Shame, sexual addiction, and consumption in American culture. Sexuality \& Culture, 19(3), 413-425.

Johnson, S. (2008). Hold me tight: Seven conversations for a lifetime of love. Little, Brown \& Company, New York, NY, USA.

Katehakis, A. (2017). Sex addiction as affect dysregulation. New York: W. W. Norton \& Company, Inc.

Katehakis, A. (2010). Erotic intelligence: Igniting hot, healthy sex while in recovery from sex addiction. Health Communications Inc., Deerfield Beach, FL

Kernberg, O. (1998). Love Relations: Normality and Pathology. Yale University Press.

Lee, B. (2012) Towards a relational framework for pathological gambling (Part I): Five circuits. Journal of Family Therapy doi.org/10.1111/j.1467-6427.2012.00588.x

Lee, Y. and Ko, Y. G. (2018). Feeling lonely when not socially isolated: social isolation moderates the association between loneliness and daily social interaction. Journal of Social and Personal Relationships, 35(10), 1340-1355.

Lie, S. (2016). From Shame to Drive: The Waning of Affect; or, The Rising of the Drive Image in Contemporary Hollywood Cinema. Social Text, 34(2), 45-70.

Lykes, V. A. and Kemmelmeier, M. (2014). What predicts loneliness? Cultural difference between individualistic and collectivistic societies in Europe. Journal of Cross-Cultural Psychology, 45(3), 468-490.

Malin, B. (2005). American masculinity under Clinton: Popular Media and the Nineties

"Crisis of Masculinity". New York; Oxford: P. Lang.

Morgan, D.H.G. (1992). Discovering Men. London, Routledge. 
Perlman, D. and Peplau, L. A. (1984). Loneliness research: a survey of empirical findings. In Peplau, L.A. and S. Goldston (Eds.), Preventing the harmful consequences of severe and persistent loneliness (pp. 13-46). Washington: U.S. Government Printing Office

Raw, L. Çağan Irmak: Yeşilçam Revisited, (89-11). In L. Raw. Six Turkish Filmmakers. The University of Wisconsin Press.

Richardson, A. (2000). Rethinking Romantic Incest: Human Universals, Literary Representation and the Biology of Mind. New Literary History, 31(3): 555-572.

Rokach, A. (2012). Loneliness updated: An Introduction. The Journal of Psychology, 146(1-2), $1-6$.

Russell, D. W., Cutrona, C. E., McRae, C. and Gomez, M. (2012). Is loneliness the same as being alone? The Journal of Psychology, 146(1-2), 7-22.

Schiller, B. M. (2021). Siblings, sex, and shame: The film Shame (2011). The International Journal of Psychoanalysis, 102(3), 603-616.

Schnarch, D.M. (1991) Constructing the sexual crucible: An integration of sexual and marital therapy. Norton \& Company, New York, NY, USA.

Shaffer, H.J. and Albanese, M.J. (2005). Addiction's Defining Characteristics. In R.H. Coombs (Ed.) 3-19. Addiction Counseling Review. Lawrence Erlbaum Associates, Mahwah, NJ.

Sternberg R.J. (1999). Cupid's Arrow: The Course of Love Through Time. UK, Cambridge University Press, 1999.

Sümer N, Güngör, D. (1999). Yetişkin bağlanma ölçeklerinin Türk örneklemi üzerinde psikometrik değerlendirmesi ve kültürlerarası bir karşılaştırma. Türk Psikoloji Dergisi 14: $71-106$.

Waddell, T., \& Waddell, S. (2021). Affect, sibling bonds and childhood sexual abuse in Shame and The War Zone. Continuum, 35(1), 30-42. 
Westermarck, E. (1925). The History of Human Marriage, 5th sd., 3 vols, London.

Yanıkkaya, B. (2010). Arsız Adam ve Bir Maymun: Feminist Film Okumaları, (187-215)

In M. İri (Ed.). Sinema Araştırmaları: Kuramlar, Kavramlar, Yaklaşımlar. İstanbul: Der Yayınlar1.

Yüksel, E. (2013). Babalar ve oğullar: 2000'ler Türkiye sinemasinda erkeklik krizi. sinecine: Sinema Araştırmaları Dergisi, 4(2), 41-67.

Zapfö J.L., Greiner J, Carroll, J. (2008). Attachment styles and male sex addiction. Sex Addict Compusivity 15: 158-175.

\section{ENDNOTES:}

${ }^{1}$ [Editor's Note]: Both Shame and Alone have been studies previously through different theoretical approaches varying from queer theory to Marxist and psychoanalytic approaches. For Shame see Iwen (2015), Lie (2016), Schiller (2021) and Waddell and Waddell (2021), and for Issiz Adam/Alone see Yanıkkaya (2010), Yüksel (2013), Akser (2016), Raw (2017) and Çağlayan (2020). The present article is unique in its use of attachment theory as a method of analysis. 